\title{
The Public Opinion In The Modern History Of Political Thought According To Jurgen Habermas
}

\author{
Enkelejda Hamzaj, PhD Candidate \\ University of Tirana , Albania
}

doi: 10.19044/esj.2016.v12n23p234 URL:http://dx.doi.org/10.19044/esj.2016.v12n23p234

\begin{abstract}
Is not easy to make in a few lines a presentation of Habermas's thinking regarding to public opinion in the history of political thought. One of the most interesting sections of all habermasian discussion - developed not only in his opera History and critiques of public opinion but in others too - lies in clarifying how the public opinion concept was evaluate by philosophers of different political orientations during the modern era.

According to Habermas, to do this analysis should go under the tracks of Hobbes, Rousseau, Kant and Hegel. Some of these authors appreciate and value the role of the public opinion while others do not believe in its function. It is not a coincidence that the"classic" treatment of the public opinion concept culminates with Kant, the author, who is considered one of the greatest luminaries in Europe. While we find in Hegel a devaluation of the public opinion, compared with the science, and this depreciation is parallel to the depreciation of the civil society against the State.

On the other side we will see other contemporary authors analysis regarding public opinion, like Nicola Matteuci and Giuseppe Bedeschi and their thoughts compared with Habermas thoughts.

To understand the function of public opinion I will show its specific characteristics throughout history from the Greek polis up to the French Revolution and the creation of the bourgeoisie class.
\end{abstract}

Keywords: Public opinion, function, class, civil society, the bourgeoisie

\section{Introduction}

Before I go on the historical story according to Habermas manner, where he tells the public opinion position in the modern european society, I think it is worth noting the sharp criticism, through which the philosopher wanted to characterize the public opinin concept.

We should note that in a theoretical perspective, for the philosopher, the public opinion is characterized of a dualism form. The Public of public 
opinion stay so natural in its content and has nothing to do with private affairs of an individual or another, with one group or another but it has to do with the public or said it differently in latin - like Habemas does - la res publica.

Meanwhile is revealed another sense of this opinion public, the fact that public opinion is like this because is realized under "the sunlight". In this way the public opinion appears as the perfect antithesis of every secret meeting. Where the agreements between individuals tend, at least in part, have their dark and secret character, the public opinion for its nature is open to all.

It's not a coincidence that public opinion is created in West at the same time with the genesis and affirmation of Greek polis. In fact these were the first democratic regimes, which have left a mark on history. In an institution with weak vertical structure of power - as notes Nicola Matteucci, in sincrom with Habermas thought,- The Greeks were the first to look for big debates in public squares (exactly agora) to discuss the political and administrative issues of the day, to appoint or cancel different labor positions, etc.. ${ }^{15}$.

Also we should remember that public opinion, precisely in virtue of Hellenic origin past but rooted, has always the doxa or epistemology character. Regarding doxas it has the opinion character to looking the things, in total contradiction with what characterizes the scientific discussion led by rigorous methods, so the epistemology.

In another book dedicated to public opinion, Habermas has expressed that, in its being, not epistemological, we have both strong and weak point ${ }^{16}$. The weak point if we want to call it like this, stay on the fact that we are talking about opinions, points of view that doesn't necessarily presuppose the indisputable conclusion of the truth which is part of science. Exactly this moment lack of rigor inside of the public opinion, has always exploited in centuries, the opponents of democracy, since Plato in his book The Republic ${ }^{17}$. The public opinion is like this because it is the opinion of "the public". Individuals who have vital interests on a specific issue and don't have specific competencies (legal, administrative, economic and financial, cultural, etc.) Some others u leverdis opinioni, variable point of view, sometimes unilateral; an infallible critical precision of the mathematician or the philosopher ${ }^{18}$. So, he does not attempt to present the truth, to materialize it. However, what may seems a weakness of the public

15 Price,V., (1993). L’opinione pubblica, Bologna, Il Mulino, p. 9.

16 Habermas, J., (1978). Teoria e prassi nella società tecnologica, Roma-Bari, Laterza p.111.

${ }^{17}$ Habermas, J., (2001). Verità e giustificazione: saggi filosofici, Roma-Bari, Laterza, p.133.

${ }^{18}$ Habermas, J, from Ceppa, L., (2007), Morale, diritto, politica, Torino, Einaudi, p. 48. 
opinion, appears as one of his unquestionable strong points. In fact the pretense of the truth possession, first of all from political point of view (authoritarianism, oligarchy), get into dogmatism. While, in the moment that public opinion is the result of the public debate, is positive the fact that for principe it is excluded from any dogmatic rigidity. It is always ready to oppugn the taken positions. As such, the public opinion is traversed from current disagreement, different points of view: all these remain the essence of democracy ${ }^{19}$.

One of the most interesting sections of the Habermas debate, developed not only in the The Structural Transformation of the Public Spherebut also in other works, make a clarification of the way how during the modern era, philosophers of different political orientation have welcomed and valued the concept of public opinion.

According to Habermas, we should follow the steps of Hobbes. In fact, it is known that this great philosopher developed his reflections around the mid of 600s, when the crisis of the English absolute monarchy started, which ended with the murder of Charles I Stewart and the affirmation for the first time of the Republicanism in the Anglo Saxon world ${ }^{20}$.

Thomas Hobbes, a believer of anoppressive power and aabsolute state strickness, from this point of view could not see with a kind of disbelief the exaltation of the public opinion that meanwhile was spreading in almost all Eupope and Continent ${ }^{21}$. In the spotlight of absolute strictness, for Hobbes, the public opinion with his critics and different points of view could not appear as a potential disintegrant of the strictly unity and unconditional of the sovereign power.

Nicola Matteucci agreed with the Habermas analysis and pointed that the public opinion for Hobbes is sensitive to the punishment, from the moment that he "brings within the State a kind of anarchy and corruption" 22 . In fact, to achieve an idea or specific program, the citizens leave aside the isolated state of the individual and build the partial society that Hobbers didn't hesitate to compare with the parasitic organism, which live within a big organism (that's why it is the State) distributing the sources even those that were very dangerous. ${ }^{23}$ As always, this point of view of Hobbes has a perfect strictly logic. At the moment, when it looks for the revenge toward unity, absolute invisibility and superiority of the State towards any other force that move in the society, the public opinion could be

\footnotetext{
${ }^{19}$ Sartori, G., (1991). Democrazia. Cos'è, Milano, Rizzoli.

${ }^{20}$ Pacchi, A., (1983). Introduzione a Hobbes, Roma-Bari, Laterza.

${ }^{21}$ Habermas, J., (2003). Il discorso filosofico della modernità, Rome-Bari, Laterza, p. 69.

${ }^{22}$ Matteucci, N.,(2004).Opinione pubblica in Bobbio, N.,-Matteucci, N.,-Pasquino G., (curated by), Dizionario di politica, Torino, UTET, p. 637.

${ }^{23}$ Pacchi, A., Introduzione a Hobbes, cit., p. 71 and on.
} 
seen with a deep disbelief. The contradictory ideology arises from the public opinion, which could be potential enemies of the State. Also parties can arise, which threaten to secese from the State and to penetrate the rebellion, anarchy and distruction, as Hobbes had in mind the bloody English civil war. $^{24}$.

Vice versa, the object is not the revenge toward the unity, and the indisputable superiority of the State in the civil society,but the affirmation of the limited character of the power, the aim which should be only the guarantee of the natural rights of the individual, the concept of the public interest become important and gets value. Some decade later, Hobbes always in the Anglo-Saxon philosophic tradition, at the end of 600s, one of the greatest liberal writers, John Locke, aCalvinist and exponent of the great bourgeois did not hesitate to listen the praising of the public opinion and its function within a State, which looks for the freedom value rights aside those of authority ${ }^{25}$.

Civil society, which for Hobbes is impossible to be considered before and out of the State, from the moment that the individuals without the state authority are destined to oppose and fight each other, as in the State nature where bellum omnium contra omnes, for Locke it results to be previous from the State logically and chronologically. In fact, individuals, nowadays, know the state of civilization in the natural State. They know the private property, religious and moral life, traditions, customs, family, etc. But what is missing is the binding power precisely that of the State, in the state to resolve the disputes between yours and mine, ending the disputes between the individuals based on the norm of constitutional and public rights ${ }^{26}$. So, the State does not arise to create the civil society, but simple to guarantee the natural rights of the individual, which are parts of the civil society. In this way, it means that what the State needs to do is the consciousness, opinion and religious freedom, that later will be the main principle where derives and affirms the public opinion. In a State, where the power is limited, the variety of tendencies, parties and ideology is welcomed but inevitable. The public opinion in such a State, that today we define as a liberal and parlamentaryconstitutional represent a fundamental value nothing inevitable.

Until now, in Habermas' step, it is shown that the public opinion in the Western political tradition, at least in the modern period has had a connotation in terms of liberal, but projected to defend the individual rights against the defined powers that suppressed them.

Another very important author of 700s, Rousseau, we are in front of other direction that in a way is a turn. He is an implicit supporter of

\footnotetext{
${ }^{24}$ Habermas, J., Il discorso filosofico della modernità,cit., p. 133.

${ }^{25}$ Viano, C.A., (1997). Il pensiero politico di Locke, Roma-Bari, Laterza, p.21.

${ }^{26}$ Pacchi, A., Introduzione a Hobbes,cit, p. 141.
} 
Republicanism against any monarchy, but differently from Locke, he looks with a great disbelief the parliamentary representation. Though Enlightenment and Romanticsm, he is considered as a representative of Enlightenmentat the moment when he urges the rulers of his period to release from the Middle Agerelics that according to him were the parliaments ${ }^{27}$. So the deep reflection of Locke for the inevitable role that the parliament members have as the representatives of the people's will, so of the public opinion, is undiscussable that is overpassed. This not because Rousseau devaluates tout court the concept of public opinion. Even in some cases, he has a theological cult of the people's will. For him, the voluntas populi is voluntas dei synonym ${ }^{28}$. He is convinced that the people do not live for the institutions, but vice versa the institutions should serve the people. It is undiscussable that he excludes the political bodies, parliament members, ministers; they should have an instrumental role, as a real administrative ogan of the people's will. But how is he represented to the people's will? Every representative intervention or structure is excluded by him (we should not forget that Rousseau was Swiss, from Geneve; that's why he felt so much the experiences of cantonal self-governing, which are of a special importance in the tradition of Helvetic Republic) ${ }^{29}$.

So, the public opinion is important for Rousseau, but the difference of his thought compared with other analysed authors stay in the fact that he does not have any goal that the public opinion should seem in this indirect way, only implied. Thus means that the people do not need a mediator. They need only the union of the mass in the central squares and through a public debate to choose the ministers and the most important for Rousseau, to make laws. It is obvious that the whole institutional architecture of the liberal State, firstly the division of the tripartite division of power, cited by Locke and after by Montesquieu, overthrown by Rousseau, with the same contempt with which he is released from the parliaments, "Middle Age relics". The State could not have other power foundations expect the people that are united and enacted passionately. Derathé noticed in the classic Rousseau, a clear memory of the classicalRepublics, Greek Polis and especially that of Sparta, which with its authoritarism could not have influenced and attracted him $^{30}$.

Rousseau believes that the human being is better than the nature. It is the corruptive impact of civilization that has obscured the good aim of the human and has turned him into a corruptive creature ${ }^{31}$. The science, arts

\footnotetext{
${ }^{27}$ Casini, P., (2008). Introduzione a Rousseau, Roma-Bari, Laterza, p. 71.

${ }^{28}$ Bobbio, N., (1999). Teoria generale della politica, Torino, Einaudi, p. 61.

${ }^{29}$ Cassirer,E.,(1967). Il problema Jean-Jacques Rousseau, Firenze, La Nuova Italy, p. 137.

${ }^{30}$ Derathé,R., (1983). Leggere Rousseau, Roma, Editori Riuniti, p. 196.

${ }^{31}$ Rousseau, J-J, ( 1970). Scritti politici, Torino, UTET, p. 673.
} 
and technics instead of verifying the born kindness of the human, has helped to destroy it. Precisely, the techniques of the political art are those that contribute to rip off the human from his origin and in his alienation to understand and search for the common good.

For Rousseau, the concept of the public opinion come as a will of everyone, which gathered in assembly, approve and govern directly, without any kind of intercession or representation. We could call his ideal even utopic, opposing all the big States that now represent almost every political reality of his time.

Rousseau looks at the small State remembering the Helvetic experience, thus the State where all the citizens are connected with a moral brotherhood. All know each other, know their needs and for this reason can govern in the best way $^{32}$.In fact, for Rousseau the opinion is public in the essence and contruction. He does not contemplate any private ideals divergence, the dissent of the people gathered as an assembly is simply inconceivable for him. This is for the reason that every deviated desired is simply a bad desire that the other, those that listen and perceive appropriately the collective needs, has the right to make and to lead in the right direction even through the force if it will be necessary ${ }^{33}$.

But in the same time, this public opinion has not an artificial aspect. So, it is not an untouchable thing, fruit of the convergence and divergence of the ideals and different genres of the thought, public debate, conflict of newspaper and other periodicals, etc., that the liberal concept of public opinion has taught us. (as Habermes has emphasised). The public opinion for philosophy is transformed into a unite voice that comes from the people of the assembly, who ask for things without interest for the opponents, even oppressing them ${ }^{34}$.

One of the greatest researchers of the philosophy and political theory of the 900s, the Italian Nicola Matteuci,has given us a portrait of Rousseau as an unclear supporter and at once denying the concept of public opinion. It is worth to mention his words, even though the portrait that Matteucci gives for Rousseau it is convergent for many reasons compare to what Habermas wrote in The Structural Transformation of the Public Sphere, as follows:

"The public opinion with Rousseau continues to express moral judgement, but these werejudgements that have a direct coincidence with the politics and the institutional channel through which they are expressed. In fact, in Social Contract he reevaluates the instutite of censure, the Minister

\footnotetext{
${ }^{32}$ AA.VV., (1994). Tre letture di Rousseau, Roma-Bari, Laterza, p. 93.

${ }^{33}$ Solari, G., (1985). La formazione storica e filosofica dello Stato moderno, Napoli, Guida, p.54.

${ }^{34}$ Matteucci, N., (1984). Alla ricerca dell'ordine politico. Da Machiavelli a Tocqueville, Bologna, Il Mulino, p.14.
} 
of the Law of public opinionbeing the censor: "As the law is the declaration of the general will, the censorship is the declaration of the public judgement”. The censor is not the referee of the people opinion, but only his expression and could not get away from the habits, thus if the censure is useful to preserve the habits, it has not replaced them when they are corrupted. Rousseau "general will" wanting to overpass the distinction between the politics and moral shows the tied correlation between the peoples'sovreignity and public opinion, laws and customs and sees in the public opinion "the real constitution of the State". Rousseau could not develop his discussion as the fact that in his direct democracy could not give the tension between the private and public spheres, of the modern State himself within which spaces for the public opinion are created, and also because he defines the public opinion as costumes or habits, whichare the heritage of the past or are formed spontaneously and are not the fruit of the rational public discussion, as a genuine public opinion" ${ }^{35}$.

So this part is really relevant exactly because - as we posed-there are registered a series of important convengences with Habermas reflections. Even the German researcher, as the Italian one, tries to highlight that the concept of public opinion of Rousseau discovers an unclear value, which should be clarified. On one hand, it is obvious that since it protects the people sovereignity, he could not attribute to a kind of opinion "form". It is true that the way how he sees the public opinion, has the character of a thing that could never be private, which means unconnected, it disagrees from one subject to another. Then, Rousseau - only in this regard- seems like the lawyer of the public opinion. How could it be different from the moment that he is one of the outstanding and great theorician of the modern period? In fact, it is known that the French revolutionaries in 1789 and later, especially in 1793, see at him one of their deepthinspirator ${ }^{36}$.So, as many time that the people sovreignity is asked we should understand that the legitimate power belongs to the people, it could not be mentioned the inevitable importance of public opinion $^{37}$.

But in the same time, the concept of public opinion needs a liberal State, which gives the freedom to the thoughts through other trends. It could be said that the concept of public opinion could bloom only where it is not prejudice - as the Rousseau did - from the idea of an utopic and perfect State in which the disagreement of the thoughts it is seen as a kind of disruption or destruction. That's why, on one hand,overpassing the instiction of the

\footnotetext{
${ }^{35}$ Matteucci, N., Opinione pubblica, in Bobbio, N., -Matteucci, N.,- Pasquino,G., Dizionario di politica, cit, p. 637-638.

${ }^{36}$ Talmon, J., (1997). Le origini della democrazia totalitaria, Bologna, Il Mulino, p. 201.

${ }^{37}$ Habermas, J., (2010) Storia e critica dell'opinione pubblica, Milano, Mondadori, p. 61 and on.
} 
political ethics, Rousseau - same as Matteucci in the above mentioned part finds in public opinion "the real constitution of the State" and it is not a written constitution that is repeated as many time as the people gathered in an assembly and approved unanimously its will.

Thus, the idea of the public opinion as a product of rational public debate comes less, we can say, to Rousseau: the public opinion - as Matteucci expressed - coincides with the 'habits', then in a series of ethical and civil behaviours, which are not discussed or examined rationally but are inherited from the past and as such are accepted and not discussed ${ }^{38}$.

The concept of public opinion that takes these forms in Rousseau is confirmed again by Matteucci from the reference that he does to the censure.The public opinion, as it is perceived in a liberal optic, does not look kindly upon censure: In fact, it is only an institute where some people pretend the right to oppose the free demostration of the other people thoughts only for the fact that they are considered as unapproriate and do not match with the majority opinion. So, in the political thought of Rousseau, there is no place for minorities, for the dissent voices or each element that represent the liberal authentic civilization. That's why, with a contradiction only for the outside, he is considered as the father of the modern democracy but at the same time even the enemies of the liberalism. He is considered as one of the well-known descendent of "totalitarian democracy" as it appears in the title of the classic book of Talmon.A democracy that is denied the public opinion as a free movement and rational debate of divergent opinions, but for some reasons pretend to reaffirm not as a written constitution of the State but as a group of habits on which the state civilization is build.

Thus, a uniform public opinion, as a regiment in which the vigilent institute of censure prevails, is translated in the oppression of the disidents from the majority. No wonder that the scary phrases which appears in an important moment of Social Contract, that is the most important political work of Rousseau, according to which the aim of the State is "to urge each one of us to be free” he writes:"To force some to be free" or to know what is its authentic freedom that coincide with the general will from which, he, the careless, pretend to get away ${ }^{39}$. Precisely because its republicanism is a form of democracy without liberalism - noticed Habermas- saysRousseau but on the other hand it denies the foundations of the public opinion.In fact, the public opinion noticed the German philosopher and sociologist is entirely (das Ganz) that consist from the melting of each part (teil). These parts, which are united to give life to a whole, naturally are not, expect individuals,

\footnotetext{
${ }^{38}$ Matteucci, N., Opinione pubblica, in N. Bobbio, N., -Matteucci, N.,- Pasquino, G., Dizionario di politica, cit., p. 637.

${ }^{39}$ Rousseau, J.-J., (1970). Il contratto sociale, in J.-J. Rousseau, Scritti politici, p. 742 and on.
} 
which formed a common conviction, with critic values, which is presicely that of public opinion.

Thus, why should we have public opinion in its tensed formation, with internal divisions and tension in thousands channel, etc., that are presicely those that Rousseau condamn and could not value, it is necessary to guarantee the freedom of each one. This is the reason that according to Habermas become necessary to take another step or the rise of a perspective, from the pure republican democratism to liberalism.In historic and philosofic terms, it is necessary to go beyond Rousseau to reach the author when the Enlightenment is at its peak and in generally the European modern philosophy, German philosopher Immunuel Kant.

Which is the function of the public opinion in the liberal State according to Kant? He is one of the first author of the history of contemporary political thought that has done a critical analysis of the adjective public and why the noun complement the word publicity ${ }^{40}$. The Kantian political writings are different where the thematic of the public is found intensively and systematically. For these reasons, it is worth to bring back - even Habermas cited the fundamental writing "What is Enlightment?" where Kant has urged the readers "to make public his reasoning in all the fields" 41 .So, it is a public use of reason in the sense that he writes, debates, arguments or simply sets a discussion on a subjet of common interest, never speaks, he can not speak ever says Kant, as a subject of purely personal but always as a citizen, a member of civil consortium.

Even Matteucci, with some pervasive considerations, that without doubts, match those of Habermas. The receiver of a public use of the reason is double, especially in a political regime - emphasizes Kant - still characterized by the absolute feeling. On one hand, naturally the people, which benefitting from the public use of the reason, become more and more able to act critically and conscious for their fate.

On the other hand, the fate is the absolute State itself, which it's important to show - saysMatteuci, rephrasing Kant - that do not have advantages to treat the human the same way it is treated a $\operatorname{car}^{42}$. So, the human- writes Kant -is not treated according the regulation "of police State", but according to the human dignity that belongs, that is in him and inalienable from him ${ }^{43}$. The reflection of the public core of Kant

\footnotetext{
${ }^{40}$ Solari, G., La formazione storica e filosofica dello Stato moderno, cit., p. 99.

${ }^{41}$ Ivi, p. 103.

${ }^{42}$ Kant, I, (1973). Che cos'è l'Illuminismo?, in Kant, I., Scritti politici e di filosofia della storia, Torino, UTET, p. 79.

${ }^{43}$ Ivi, p. 130.
} 
continues to develop further even in some his unforgettable political writing where we mention the well known workPerpetual Peace. In this work, Kant is distanced by any "governing" concept (at least potentially authoritarian, autocratic and not liberal) of the culture and in general of the debate that has to do with the ideas.

"Firstly, the people could not enlighten the official people of the State for its rights and obligations, but experts or specialists of the rights, philosophers.Disbelief in government, which looks always to dominate, it is emphasized the distiction between the politics and moral, the indipendence of civil society, composed of indipendent and rational individuals from the State" ${ }^{44}$.

And where then is the importance of "publicity"? Kant does not hesitate to treat this problem noticing that "publicity" as a synonym of "public opinion” empower its meaning appears as a intermediate element or precisely as a mediator between the politics and moral.Thanks to publicity, he notices that the politics is forced to kneel down before the moral" 45 . In fact, especially because the politics do not know other than the strong law of usefulness, tent inevitably to dominate, returns in interest only to one part not the whole of it as it should be in reality. Vice verse, Kant notices that the politics could be the cultivation of universal interests only in the moment when it is distributed, enlightened and uprised in ethical ideals.

Now because through the politics and moral, it is tented more often to create a disagreement, and it is the politics the first that denies the reasons of the ethics, public opinion develops his function precisely remembering politics which is its horizon, that of universal values in which the politics should serve not oppress ${ }^{46}$.

The public opinion is composed of a kind of space that even though is not institutional it is recognized judicial thanks to the free speech and debate. Through gubernaculum (meant as an instrument and place where the power is managed and exercised) and the rank of citizens as private, the public opinion sphere is rised as a bridge that connect and unite the private and State. The public opinion through newspapers, journalism but over all through critic, philosophic and political reflection, and "principle mirror" is done: so, time after time executives could see the reflection of their image in the concept that the people has created.They will be evaluated, offended or censured urging to change the ways of actions ${ }^{47}$.

\footnotetext{
${ }^{44}$ Matteucci,N., Opinione pubblica, cit., p.637.

${ }^{45}$ Kant, I.,Che cos'è l'Illuminismo?, cit., p.160.

${ }^{46}$ Matteucci, N., Opinione pubblica, cit., p.638.Compared with the thought of J. Habermas, Storia e critica dell'opinione pubblica, cit., p. 66 and on., where are developed the same thoughts with Matteuci.

${ }^{47}$ Kant, I., Che cos'è l'Illuminismo?, cit.,p. 101.
} 
One of the cases that has treated Habermas, is divided in the same intellectual point of view from some other authors, it is precisely what Kant says that the concept of public opinion is at its peak defined as a kind of "classic" statement ${ }^{48}$. This should surprise us. In fact, the Enlightment was called the century of enlighteners. The latest were the light of the reason that keep away any superstition, darkness and in this way preprared - at least what they believed-an excellent future for humanity. There were less illitarates, superstitians, ignorants, and in the political plan there less dictatorship, the latest replaced from a politic build on rationality, freedom and precisely on public opinion.

It is not coincidence that the "classic" treatment of the concept of public opinion culminates with Kant, the author that is considered one of the German great enlighteners but also of Europe ${ }^{49}$. Later, the French Revolution started, through which are shaped the liberal and democratic ideals in Europe. However, at the same time, the degradation of the French Revolutionin the turbulences of terror, and after the authoritarianism of Napoleonic period, and the first half of the $800 \mathrm{~s}$, a period that favored the public opinion started. The freedom of speech and of opinion not only was not tolerated but also oppressed openly. During the 800s, denying the fundamental achievements of the previous century, the concept of public opinion was fading away entering in a real crisis.

At this point it is worth to mention - based on an author that for some reasons is close to Habermas, as it is mentioned above Matteucci and also the intellectual journalism brings the debatable and contradictory sides of the public opinion concept. What happened in 800s, a century dominated by romanticism, very often had anon direct orientation toward the abstract rationality of the Enlightenment Era ${ }^{50}$. A devaluation of public opinion, compared with the science, it is found in Hegel Philosophy of Right; and this devaluation is parallel with that of the civil society against the State.

For Hegel, the public opinion is a manifestation of the judgements, opinions and advices of the privates for their work in general, but is recognition other then phenomena, as a union of subjective views, that have a formal majority that does not oppose the severity of the sciences. In the same way, the civil society, in which is formed the public opinion, is a union of anarchic needs and antagonists that do not eliminate the inequalities. You could not reach the universality through special interest, because the civil society is not organized: for this the self understandings of the public opinion

\footnotetext{
${ }^{48}$ Habermas, J., Storia e critica dell'opinione pubblica, cit., p. 36.

${ }^{49}$ Cassirer,E., (1982). Vita e dottrina di Kant, cit.

${ }^{50}$ Cassirer, E., (1976). La filosofia dell'Illuminismo, Firenze, La Nuova Italia.
} 
is not representated as a reason; and if through the legislative power of the Rule of Law, the class of the privates is increased in the universal things participation. The State is changed with the civil society, bringing its disorganization within the State, which if wants to be universal, should be organic (traditional). In the organic State we have the integration of the citizens from the top, a leap of the civil society, a transition from the good sense of the "science", possible in politics only when you see in the State view the carnation of the absolute Soul. We found in Marx a similar devaluation of the public opinion in A Contribution to the Critique of Hegel's Philosophy of Right. In Jews Questions, he noticed that in the creation of the "political State" the civil society is neutral and depoliticize based on the classes and corporations opposing from one hand the private individuals and on the other hand a political universal soul that is predicated to be independent from special elements of the civil life.

The public opinion is only a false knowledge; ideology because in a societ divided in classes, covers only the interest of the bourgeois class. The audience is not the people, the bourgeois society is not a whole society, bourgeois is not citoyen, the private public is not the reason. The public opinion is only the ideology of the bourgeois Rule of Law. However, with the expansion of the universal votes, there is a tendency of the civil society to create a political existence: the weapon of the public, created by the bourgeois tent to return against it. When the civil society will have a fulpolitical existence, with the class abolition it will cease rejecting the State, because the new classes not bourgeois will not have interest to keep the civil society as a private sphere divided by the politics. Only then will the public opinion realize that the full rationalism of the political power, up to abrogation, because the political power is build in a way that one class oppresses the other. The political power will merge in the social power, and thus the public opinion could perform all its political functions; and the disappearance of the private sphere, will be the identity between home andcitoyen.

Even the liberal generations after Constant and Bentham begin to think that the public opinion was not that "uncorrupted" as it was believed before: the risk of corruption did not come from the government but from the civil society itself, through despotism of the majority or the conformism of the mass. Alexis de Tocqueville in Democracy in America, and the same thought even John Stuart Mill in On liberty shows how the despotism of the mass does not operates through public authorities, executive organs of the State but as a psychological pressure form the side of the society to the soul and not to the individual physic and because of this it has to choose between conformism and marginalism. There is a social control more than a political one that does not allow the free development of the individual personali and 
creation of the audience with rational individuals. The crisis of the public opinion comes as a result of two other factors: on one hand the eclipse of the reason that shows its legimate that practically it is useful and available for the prosperity, which it is reduced in a market account and does not look any more in a rational dialogue for universality of the opinions; on the other hand "the cultural industry" transforms the intellectual works into simple goods destinated for success and consumption and the desire of glory is replaced with that of the money. The ideal dialogue between the enlightener and its public that Kans sees does not have the conditions to be realized. The critic sociology of 900s takes some thoughs fromToucqueville, to show the disappearance of the public opinion. As the "great" win, the countries that had allow the formation of the rational dialogue of the public opinion disappear: in stead of the salon there is the television, the newspaper were converted into speculative corporations, organization and parties leaded by the oligarch, the spaces of the public opinion formation were not self manageable but were administrated by the powerfullburocracy.

Meanwhile, the contemporary state, it is less visible the division between the State and the civil society, as one has describe the other, and leading calss is formed, interested to dominate, and could easy manipulate the public opinion. This thing could be adjust only if instutional space is created, that allows the effectiveness of the freedom of speech, of press through a real participation of the citizens toward the public opinion formation: the organization should be forced to control the means of the mass communication, to perform their functions toward a dialogically formation in a process of the public communication and not that of the manipulation of the atomized public, that now has in "the public" not a instrument of the rational freedom but the slavery toward the productive system. So, the institutional elections should be created to give to the public the element that distinguished it: critics. The experience of the totalitarian regime, in which "the public" Kantian is converted into a propaganda, the existence of the new technology of the mass communication, that disinform from the critics and ruin the image of the public opinion. However, the mass myth, totally passive toward the public is dipel and as a result the public opinion should be affirmed where the freedom of speech and thoughts exist, a pluralities and pluralism of the authonom informative organs, which means not controlled by the politicians: in this polycentrism balances the public opinion is formed in a dual process, that rise form the bottom to the top and vice versa, through the leaders of the opinions in local and national level" ${ }^{51}$. The gold period of public opinion for Habermas was precisely the 700s: an era where the birth and the spread of

\footnotetext{
${ }^{51}$ Matteucci, N., Opinione pubblica, cit., p. 638-639.
} 
Enlightenment, and especially thanks to two great revolutions - American and French - sees precisely the principle of autodetermination of the people triumphing and refusing any imperialist claim (in the case of America) and absolutist (in the case of France). So, in the moment where there is no constitution, parliamentary government, there is no formal and legal inequilties of the citizens before the law, then we will not have an available concept of the public opinion, Habermasemphasises. Then why the public opinion century - as we see in the above exposure Habermasian - is the century that knows the transparency of the journalism, press, clubs and organizations. Bourgeois century is the century of the rational debates that shed light where there are the critics of enlighteners-form the high intellectual spheres of the Volteir, Diderot, D’Alambert, etc. -little by little go down, pour on all the bodies of the society and stays precisely in the those bodies (bourgeois) that are represented as mediator of the revolution, of the change $^{52}$. After the French Revolution, even the despotic and demagogic regression that this has with the so called Terror, it is the period of Napoleon ${ }^{53}$. After the fall of Napoleon Bonaparte, it started the period that is known as the period of the Restoration ${ }^{54}$. Established on the principle of the royal throne alliance, that was the "restoration" of the legitimate sovereigns that the period of Napoleon has fallen and now, after his fallen returned to their positions. If we return to the antique period, only formally, the liberal, democratic, republican ideals were not looking kindly upon, which from what is treated above are the same with the public opinion. That's why, at the same time with the return of the absolutism of that period, constitutions, free and parliamentary governments will start to be the object of the critics and disputes in many ways. Not only that it is understandable, Habermas said, from the govermentals and in general from those that have the interest to restore the absolutism; but also from the side of the independent intellectuals, which thought that the return of the Restoration was also the effect of the natural correction and biassed assignee and great distortions that the revolutionary period, and after that of Napoleon has brought.

That's why the great political conservatory writers of the Restoration era kept a great special value, as thanks to their works -Habermas says-for the first time emerged the bias, abstractions, theoretical inadequacy, for example, the contradictory, legal, natural concepts of the State, which - to express it in the Hegel language - are created to raise the State from the

\footnotetext{
${ }^{52}$ Habermas,J., Storia e critica dell'opinione pubblica, cited,p. 61.

${ }^{53}$ Lefebvre,G., (1989). Napoleone, Roma-Bari, Laterza, p. 19.

${ }^{54}$ Della Peruta, F., (1989). Storia dell'Ottocento, Firenze, Le Monnier,expecially chapter III
} 
arbitrary and capricious agreement of private individuals, exactly a contract $^{55}$.

In fact, to affirm the value of the public opinion, will mean to affirm the trust in the people believe to build their fate, meaning to criticize the actual one, the absolute State that until that moment is considered as the solution of every critic.

Regarding the latest the Kant's work mentioned What is the Enlightenment, is really similar.In this work, it is affirmed one of the glorious phrases that in their use enforce the essence of the Enlightenment. Kant writes that if we could define the Enlightenment it will be as this motto:

"Sapereaude! Have the courage to use your own understanding!" 56

So, the bourgeois, the one that gives power and life to the public opinion as an opinion that expresses the common interest, the one that with its opportunities, resound the trust in a constructive and critical force of the reason, that the great teachers of the Enlightenment has expressed. Now, in the Restoration era, in which we said that the return the principle of the alliance of the throne and kingdom, the aristocracy retake the privileges that have lost and the power is returned to absolute or unswayed power, it needed to report to anyone about they do, it is the concept of the public opinion that starts to depreciate and criticize in many ways.

So, the image of Hegel, it is very crucial at this point. It is worth to mention the quotes of Matteuci, that it is mentioned above, as the researcher has the merit of the paralleling that in Hegel pass through the antithesis public opinion-science, where the first term is depreciated compared to the second, and the antithesis State-civil society, where the first place belongs to the State, taking into account that the civil society is an important and unexcluded moment but destinated, according to the Hegel view, to resolve the supreme unit of the State.We saw above that Habermas-developed the topic in a more sociological view -sees the public opinion, at least in its golden time, as ideas toss, which are elaborated from intellectuals in a way that the prejudice of the concepts that they did not meditate and create in primis but were gathered to give their reflection, turning it into a political controversy weapon. This process, that reading Habermas, seems without doubt physiological and inevitable in the view of the thinker and conservatory as Hegel, it brings out a very important problematic. In fact, exactly because it is about the reflection of ideas, which do not deepen or widen in their authentic and critic concept, the public opinion, you like it or

\footnotetext{
${ }^{55}$ Topics treated in the classic work Rosenzweig, F., (1976). Hegel e lo Stato, Bologna, Il Mulino.

${ }^{56}$ Kant,I., Che cos'è l'Illuminismo?, cit..
} 
not says the great German author, are displayed as a series of repeated ideas without a critical, contraversial and fake basis.

It is said even above that for Hegel the public opinion is not only a phenomenal knowledge: where we need to see the antithesis of the views against Kant. In fact, the strictly knowledge is the only valid and controlled knowledge that is given to the human. While for Hegel, which overpassing the dualism of the phenomena of the reason (reasoning idea) typical of Kantianism, find grounds to exaggerate the reality thanks to the unlimited power of the reason, gathering the ideas of the reason that are after the appearance of the things, phenomenal knowledge means contingent, accidental, arbitrary and not coherent knowledge. So the public opinion, Hegel says, deserve to formulate in singular. It is in its composition the essence of being multiple, plural; to be such, thus a serie of arbitrary, not coherent and confused views with each other. In this way, the public opinion is divided in many ways of seeing, ideas, prejudices, any kind of unity and accurancy.

As the Rosenzweig says - the analysis, which correspond with that of Habermas - could not have a bigger and sustainable rejection of the enlightenement politics ${ }^{57}$. In fact, the public opinion, as we perceived even today within the liberal and democratic society as the iron spine, due to which the civil society force the government to return in its steps, to revalue its positions, to be responsible and in each case the government is not the only one to govern but always exist a civil society that observe it and it is ready to criticize it.For Hegel, it is not a very important. The civil society is a kind of contradiction that lives -as Hegel says in one of the paragraphs ofElements of the Philosophy of Right (paragraph 315-318) ${ }^{58}$.

It is difficult not to quote the thoughts of an author as Bedeschi (another author that has the same thoughts with Habermas). According to thim, "even more closed in comparisson with Kant; it is the position of Hegel regarding public opinion” 59 .

Undoubtedly, it will be biased and untrue to say that Hegel operates a single critical solution of the public opinion. The public element could not be eliminated (it could not be different from a theoretician as him for the State). In fact, many times in Elements of philosophy of right, he said that the House and the Senate, - Lower House where the representatives of corporations and the Upper House destined to the aristocrats - are obliged to manage their

\footnotetext{
${ }^{57}$ F. Rosenzweig, F., (1976). Hegel e lo Stato, Bologna, Il Mulino, p. 69 .

${ }^{58}$ G.W.F., (2012). Lineamenti di filosofia del diritto, Rome-Bari, Laterza. (the original volume appeared in 1812).

${ }^{59}$ Bedeschi, G.,(1996). Opinione pubblica, in “Enciclopedia delle Scienze Sociali”, Roma, Istituto dell'Enciclopedia Italiana, vol. VI.
} 
debates publicly. As Habermas noticed, Hegel does not want to get rid of the publicity of parliamentary debates ${ }^{60}$. Governmental and ministers, could not imagine to govern the State as their private property. Naturally, Hegel is more responsible than State exactly due to the fact of being universal and divine, is the res publica.

Then which is the function that Hegel gives to the strictly public parliamentary debates? It is about a function, we can say "political pedagogy" 61 . So, as it seems, the conservator position of Hegel is very clear. He accepts only one movement, from the top to the bottom. It belongs to the governmental, ministers that educate the public, civil society and not the vice versa. We could say one more that the words of Bedeschi seem very suitable, who says:

"Hegel gives a big important to public parlamentary debate, as an educational instrument of public opinion: he uses the phrase die öffentliche Meinun. He excludes the oppose movement, the one that the public opinion can affect the Houses transmeting them his own spirit and problems"62 .

It is about a part which explains many ideas. In the end, to Hegel the civil society appears without its own light. It could only follow the private works pointing out the topic of "system of needs"(thanks to which he appears as one of the first philosophers capable in understanding the fundamental importance of the political economy for modern society). However, in the political plan, the Hegelian civil society is powerless. Here is worth mentioning again the words of Bedeschi, according to Hegel: "the people is considered without its monarch, without bureaucratic and state organization and without corporations that give a community structure of the middle stratum (artisan , industrial and commercial) is for Hegel "the part that does not know what it wants", then he says "to know what you want, whatever will that is in itself, the reason is the fruit of a knowledge and deeper infiltration, which is not part of the people" ${ }^{\text {. }}$.

So, this deeper infiltration and knowledge is part of the politicians, bureaucratics, of those that shape the political will with rules, institutes and offices. (at this point, he defines the bureaucracy as a class that is not a class ormany other times as the general class $)^{64}$. Thoughts not similar to those of Bedeschi, we find in Habermas, who even though it is responsible for the importance and the vitality of the Hegelian thought, could not understand how the conservatism of Hegel inevitably brings to the abrogation of public opinion as the

\footnotetext{
${ }^{60}$ Habermas,J., Storia e critica dell'opinione pubblica, cit., p. 199.

${ }^{61}$ Weil., E, (1988). Hegel e lo Stato, Milano, Guerini, p.63.

${ }^{62}$ Bedeschi,G., Opinione pubblica, cit.

${ }^{63}$ Ivi, p. 713.

${ }^{64}$ Rosenzweig,F., Hegel e lo Stato, cit., p.39 and on.
} 
government stimulant and corrective. Let's see again the Hegelian view regarding the important of political pedagogy of the public debate. The movement for education and correction goes from top to the bottom and vice versa. It is the government, the monarch with its ministers, up to bureaucratics, which implement their wills, with legal norms and others that remain, thus the civil society members could learn from those that know more. A vision with the demagogy of Terror, where the potential of public opinion is reduced and it is noticeable the disbelief that the energey of the people, left aside, had had especially at the end of French Revolution ${ }^{65}$. So, even Habermas always thought that seeing a kind of ideal regression in the transition from Kant to Hegel in the public opinion concept.

\section{Conclusion}

In this way, we notice how original is Habermas thought on his approach to analyzing many authors idea regarding the public opinion.

In view of the german philosopher formation and the point of achieving its trajectory we could say that he put together in a logical flow the philosopher's thought rebuilding the concept of public opinion in years. Habemas, putting in front of the State to civil society shows how the other authors see the role of public opinion.

In the bourgeois world, the civil society is distinguished by the state and is characterized by Hegel as the "system of needs" or mutual spread of trade and manufacturing activities. For Habermas this means that the attempt for constructing the meaning of the democracy, would be realized starting from the attempt with the historical-genetic substance of the essential phases through wich, in Europe, the public opinion is affirmed as the backbone of democratic processes.

\section{References:}

AA.VV., (1994) Tre letture di Rousseau, Roma-Bari, Laterza.

Bobbio, N., (1999).Teoria generale della politica, Torino, Einaudi.

Bedeschi, G., (1996), Opinione pubblica, in "Enciclopedia delle Scienze Sociali”, Roma, Istituto dell’Enciclopedia Italiana, vol. VI.

Casini, P. (2008). Introduzione a Rousseau, Roma-Bari, Laterza.

Cassirer,E., (1967). Il problema Jean-Jacques Rousseau, Firenze, La Nuova Italia.

Cassirer,E., (1982). Vita e dottrina di Kant, La Nuova Italia.

Cassirer, E., (1976). La filosofia dell’'llluminismo, Firenze, La Nuova Italia.

Della Peruta, F., (1989). Storia dell’Ottocento, Firenze, Le Monnier.

G.W.F., (2012), Lineamenti di filosofia del diritto, Roma-Bari, Laterza.

${ }^{65}$ Habermas,J., Storia e critica dell'opinione pubblica, cit., p.171 and on. 
Derathé,R., (1983). Leggere Rousseau, Roma, Editori Riuniti.

Habermas, J., (1978) Teoria e prassi nella società tecnologica. Roma-Bari, Laterza.

Habermas, J., (2001). Verità e giustificazione: saggi filosofici, Roma-Bari, Laterza.

Habermas, J, from Ceppa, L., (2007). Morale, diritto, politica, Torino, Einaudi.

Habermas, J., (2003). Il discorso filosofico della modernità, Roma-Bari, Laterza.

Kant, I., (1973). Che cos'è l'Illuminismo?, në Kant, I., Scritti politici e di filosofia della storia, Torino, UTET.

Lefebvre,G., (1989), Napoleone, Roma-Bari, Laterza.

Matteucci N., (2004). Opinione pubblica, in Bobbio N.-Matteucci N.Pasquino G. (a cura di), Dizionario di politica, Torino, UTET.

Matteucci, N., (1984). Alla ricerca dell'ordine politico. Da Machiavelli a Tocqueville, Bologna, Il Mulino.

Price,V., (1993). L’opinione pubblica, Bologna, Il Mulino.

Sartori, G.,( 1991). Democrazia. Cos’è, Milano, Rizzoli.

Pacchi, A., (1983). Introduzione a Hobbes, Roma-Bari, Laterza.

Rousseau, J.-J., (1970).Il contratto sociale,in J.-J. Rousseau, Scritti politici, Torino, UTET.

Viano, C.A., (1997). Il pensiero politico di Locke, Roma-Bari, Laterza.

Rousseau, J-J, (1970). Scritti politici, Torino, UTET.

Solari, G., (1985). La formazione storica e filosofica dello Stato moderno, Napoli, Guida.

Talmon, J., (1997). Le origini della democrazia totalitaria, Bologna, Il Mulino.

Weil, E, (1988). Hegel e lo Stato, Milano, Guerini 